\title{
Study on the Profile of Fatty Acids of Broiler Chicken Raised and Slaughtered in Industrial System
}

\author{
MARIUS MIHAI CIOBANU1, PAUL CORNELIU BOISTEANU1*, DANIEL SIMEANU1*, ALINA NARCISA POSTOLACHE², \\ ROXANA LAZAR ${ }^{1}$, CATALIN RAZVAN VINTU ${ }^{3}$ \\ ${ }^{1}$ University of Agricultural Sciences and Veterinary Medicine of lasi, 3 Mihail Sadoveanu Alley, 700490 lasi, Romania \\ ${ }^{2}$ Cattle Breeding Research Station from Dancu, lasi - 9 Ungheni Road, 707252 lasi, Romania \\ ${ }^{3}$ University of Agricultural Sciences and Veterinary Medicine of Bucharest, 59 Marasti Avenue, 011464 Bucharest, Romania
}

\begin{abstract}
Fatty acid profile and the related nutritional indices of the breast, thigh and drumstick muscles were studied at three farms, suppliers of ROSS 308 line of broilers, slaughtered at the age of 42 days. The proximate chemical composition of the commercial slaughter cuts revealed contents between 16.26-22.78\% for proteins and 1.80-7.45\% for total lipids, the breast having the highest protein and ash content and lowest values for fat and moisture. The obtained values were mainly affected by region $(P<0.001)$. Meat fatty acid profile was affected $(P<0.001)$ by commercial slaughter regions $(C S R)$ and by the interactions between CSR and supplier farms (Farm A, B, and C) at different levels. The obvious findings highlighted that Farm $B$ supplied broilers with a delivered higher content of beneficial fatty acids ( $L A, L N A, A A, E P A$, and DHA) in breasts and drumstick, while for thigh, Farm $C$ had the best results. The content of total saturated fatty acids (SFAs), monounsaturated fatty acids (MUFAs) and polyunsaturated fatty acids (MUFAs) had the highest level in the thigh $(P<0.001)$.
\end{abstract}

Keywords: broiler meat, fatty acids, lipids quality

an ever evolving and industrialized world, consumer health [1] and quality of ending meat [2, 3] and meat products $[4,5]$ are the two highlighted issues debated from technological point of view in all stages of food chain, from farm to table, food production being in a continuous transition [6]. With vertically integrated raising, slaughtering and processing technologies, the poultry meat sector is the most widespread from the processing and consumer point of view $[7,8]$, while the bird's welfare in the industrial exploitation is a commune active management practice for ensuring a positive image among the final consumers [9]. Broiler production and processing at the mass level has already been accomplished worldwide, which is why the all-time focus is relying on enhancing the quality of meat by adjusting the different meat characteristics through diet [10-18] and by keeping them at a consistent rate for the final customer at all times, especially from nutritional point of view [19].

Thistendencyin industrial practices methods seeks to build an equilibrium [20], since it is acknowledged that the managementof poultrymeatproduction, in hardcore, primarily reflects the consumption characteristics, such as juiciness, tenderness or meat flavor [21, 22].

The current research is a study case based on the need to evaluate the efficiency of a constant nutritional management performance of 3 supplier farms within the RTC Holding Company Ltd., which supplies Ross 308 broilers for industrial slaughter, the main issue involved being the evaluation of the quality of meat lipids in relationship with supplier and commercial slaughter regions for maintaining a constant quality of fresh meat delivered in retail market and for further processing sector.

\section{Experimental part}

Material and methods

Animals, slaughtering and meat samples

The Bioethical Committee of the Ion Ionescu de la Brad University of Applied Life Sciences and Environment, lasi
Romania endorsed the current experiment in cooperation with Room Trading Company Ltd. The assumption of this research has passed from the ongoing need to deliver broiler chicken meat of steady quality in all aspects, including dietary. 150 chicken broilers (ROSS 308) were considered for meat quality evaluation from 3 supplier farms within the company group (50 birds/every experimental group $(\mathrm{L} 1=$ Farm A, L2 = Farm B, L3 = Farm C) stochastically divided in a completely randomized design at the time of slaughter, 42 days old, Table 1 describing both, the entire population of birds and the selected biological material. Pre-harvest handling, transportation (between 0.25-2.75 hours), and slaughtering procedures (stunning, decapitation and bleeding) were in accordance with the implemented good animal welfare practices approved by the E.U. rules [9] after a fasting period of 12 hours (overnight) and a resting time before slaughter of 30-90 minutes. All the chickens were weighed before being slaughtered and eviscerated, the resulted carcasses were cooled and maintained at $4^{\circ} \mathrm{C}$ for $24 \mathrm{~h}$ postmortem and after, the breasts, thighs and drumsticks were separated, and frosted at $18^{\circ} \mathrm{C}$ for use in chemical analysis (brute chemical composition and fatty acid profile).

All the farms from the experimental design applied the same industrial technology of raising: population with 1 day chicken broilers on the same day, biological material purchased from the same commercial hatchery; accommodation in a deep litter (chopped straw with wood shavings in a ratio of 60:40) in climate controlled facilities with a photoperiod of 23 hours of light/day 'till 7 days old and 18 hours light/day starting on the $8^{\text {th }}$ day of life, the environment temperature ranged between $20-25^{\circ} \mathrm{C}$ and $\mathrm{a}$ stock density of $33 \mathrm{~kg} / \mathrm{m}^{2}$ in accordance with welfare E.U. Directive [9].

All birds were fed a starter, grower and finisher diet, with ad libitum access to water (using a nipple water system) and corn-wheat-soy diet (Table 2), formulated to meet the nutrient requirements for finishing. To improve feed

\footnotetext{
*email: paulb@uaiasi.ro,dsimeanu@uaiasi.ro
} 


\begin{tabular}{|l|c|c|c|}
\hline Items & LI (Farm A) & LI (Farm B) & LI (Farm C) \\
\hline Broilers population, (N) & 98560 & 105600 & 112640 \\
\hline Broilers at slaughterhouse reception, (N) & 98353 & 105435 & 112552 \\
\hline Mortality during transport, (\%) & $0.21 \pm 0.01$ & $0.16 \pm 0.01$ & $0.08 \pm 0.01$ \\
\hline Experimental groups & $2539.87 \pm 50.22$ & $2695.01 \pm 40.10$ & $2613.64 \pm 3.25$ \\
\hline Live weight at slaughter, (g) & $1804.59 \pm 37.78$ & $1969.02 \pm 29.58$ & $2049.22 \pm 28.74$ \\
\hline Hot carcass weight, (g) & $71.05 \pm 0.49$ & $73.21 \pm 1.10$ & $78.40 \pm 1.09$ \\
\hline Hot carcass dressing percentage, (\%) & $70.07 \pm 0.69$ & $72.19 \pm 0.97$ & $77.09 \pm 1.00$ \\
\hline Cold carcass dressing percentage, (\%) & 2.00 & 4.00 & 6.00 \\
\hline Fracture incidence, (\%) & 0.66 & 3.33 & 2.67 \\
\hline Breast with bleeding spots, (\%) & 1.33 & 4.00 & 10.66 \\
\hline Wings with bleeding spots, (\%) & &
\end{tabular}

Table 1

DESCRIPTION OF THE BIOLOGICAL MATERIAL

Data: mean $\pm S E M ; N=$ birds number raised on each supplier farm and loaded for transport;

conversion, carcass yield and breast meat yield was added a supplement of Lysine. The feed supplier performed values of descriptive parameters for diet proximate chemical composition.

Table 2

DIET COMPOSITION AND ANALYZED PROXIMATE CHEMICAL COMPOSITION

\begin{tabular}{|l|l|l|l|}
\hline Items (\%) & Starter & Grower & Finisher \\
\hline Com & 35.92 & 36.81 & 38.12 \\
\hline Wheat & 26 & 26 & 26 \\
\hline Soybean meal & 25 & 21.3 & 17.6 \\
\hline Sunflower meal & 5.8 & 8.76 & 10.1 \\
\hline Sunflower oil & 3.9 & 4.2 & 5.2 \\
\hline Monocalcium carbonate & 0.9 & 0.5 & 0.55 \\
\hline Dicalcium phosphate & 0.8 & 0.8 & 0.8 \\
\hline Vitamin-mineral premix & 1 & 1 & 1.25 \\
\hline Salt & 0.3 & 0.25 & 0 \\
\hline Lysine & 0.28 & 0.28 & 0.28 \\
\hline DI-Methionine & 0.1 & 0.1 & 0.1 \\
\hline Analyzed chemical composition, $(\%)$ & \multicolumn{3}{|l|}{} \\
\hline Moisture & 10.92 & 10.73 & 11.16 \\
\hline Metabolizable Energy, (MJ/kg) & 2932 & 2932 & 2932 \\
\hline Crude protein & 23.13 & 18.7 & 20.04 \\
\hline Fat & 3.96 & 5.63 & 6.44 \\
\hline Crude fiber & 2.77 & 3.39 & 2.92 \\
\hline Ash & 6.07 & 4.41 & 4.47 \\
\hline NaCl & 0.61 & 0.61 & - \\
\hline
\end{tabular}

Proximate and fatty acid analysis

Prior to the beginning of the assessment, samples maintained for 2 months in freezing conditions were thawed overnight, deboned, minced and homogenized. Meat nutrient content was determined according to AOAC (2000), by measuring dry matter, ash, fat (using ether extraction Soxthlet method) and protein (using Kjeldahl method) [23].

The concentration of individual fatty acids was determined in two extracts from all samples by gas-liquid chromatography (GLC). Nonadecanoic acid ( $C_{19: 0} ; 3-5 \mathrm{mg}$ ) was added to the sample (1.5-2.5 g) as internal standard (IS). The extraction of lipids from meat samples was performed with a mixture of chloroform and methanol ( $2: 1$ $\mathrm{v} / \mathrm{v}$ ), as described by Folch [24]. Next, lipid extracts were converted to fatty acid methyl esters (FAME) through a consecutive trans-esterification with methylene chloride [25-27].

Separation and quantification of the fatty acid methyl esters (FAME) was performed using CarloErba 5300 mega series gas chromatograph (GS) equipped with a flame ionization detector (FID) suited for a fused-silica Omegawax 320 capillary column type SP-2380 (60 x 0.25 $\mathrm{mm}$ internal diameter $\times 0.20 \mu \mathrm{m}$ film thickness, Supelco Inc., Bellafonte, PA). The chromatographic operating conditions were as follows: initial column oven temperature $160^{\circ} \mathrm{C}$ (programmed to increase at a rate speed of $1^{\circ} \mathrm{C} / \mathrm{min}$. and from $180^{\circ} \mathrm{C}$ to $260^{\circ} \mathrm{C}$ at a rate speed of $5^{\circ} \mathrm{C} / \mathrm{min}$.) and then maintaining it at $260^{\circ} \mathrm{C}$ for 5 minutes, the total running time being $45 \mathrm{~min}$. The carrier gas was helium at a flow rate of $1.2 \mathrm{~mL} / \mathrm{min}$. and the splitting ratio, $1: 20$. The peaks were identified by comparison with the retention times of the standard fatty acids methyl esters used -C19:0 (Supelco, 37 components FAME mix).

\section{Indices and sums calculations}

The following Eqs. were used to calculate saturated fatty acids (SFAs), monounsaturated fatty acids (MUFAs) and polyunsaturated fatty acids (PUFAs):

$$
\begin{aligned}
\text { SFA } & =\mathrm{C} 8: 0+\mathrm{C} 10: 0+\mathrm{C} 12: 0+\mathrm{C} 14: 0+\mathrm{C} 15: 0+\mathrm{C} 16: 0 \\
+ & \mathrm{C} 17: 0+\mathrm{C} 18: 0+\mathrm{C} 20: 0 \\
\text { MUFA } & =\mathrm{C} 14: 1+\mathrm{C} 16: 1+\mathrm{C} 17: 1+\mathrm{C} 18: 1 \mathrm{n}-9+\mathrm{C} 18: 1
\end{aligned}
$$
$\mathrm{n}-7+\mathrm{C} 20: 1 \mathrm{n}-9 ;$

PUFA $=$ C18:2n-6cis + C18:3n-6+C18:2n-6cis + $C 18: 3 n-3+C 20: 2+C 20: 3 n-3+C 20: 4 n-6+C 20: 5 n-3+$ C22:5n-6 + C22:5n-3 + C22:6n-3;

The algorithm of the lipids indices was based on the fatty acid composition of the intramuscular lipids extracted here, being calculated Index of Atherogenicity (IA), Index of Thrombogenicity (IT) [28, 29] and Hypocholesterolemic/ Hypercholesterolemic ratio [30] by using the next Eqs.:

$\mathrm{IA}=(4 \times \mathrm{C} 14: 0+\mathrm{C} 16: 0) /[$ MUFA $+\Sigma(\mathrm{n}-6)+\Sigma(\mathrm{n}-3)] ;$

IT $=(C 14: 0+C 16: 0+C 18: 0) /[0.5 x$ MUFA $+0.5 \mathrm{n}(\mathrm{n}-$ 6) $+3 \times(n-3)+(n-3) /(n-6)]$;

$\mathrm{h} / \mathrm{H}=(\Sigma$ MUFA $+\Sigma$ PUFA $) /(\mathrm{C} 14: 0+\mathrm{C} 16: 0) ;$

\section{Statistical analysis}

Data are presented as mean \pm SEM. All statistical analysis was performed using the software package SPSS v.20 (SPSS Inc., Chicago, IL). Fatty acid profile and meat chemical composition data were analyzed using a general linear model (GLM) with CSR (commercial slaughter region: breast, thigh, drumstick), supplier ( $\mathrm{L} 1=$ Farm $A$, $\mathrm{L} 2=$ Farm B, L3 = Farm C) and their interaction as fixed effects. Carcass weight and muscle fat content was included as corrected covariates because of variations in fatness rate. Principal component analysis (PCA) was used to explore and understand the variability of bird's meat composition by studying the correlation among the various fatty acids indices and summarizing them in meaningful components (PCs).

\section{Results and discussions}

Processing and its impacts on poultry's dietary meat have become more worrying in recent years. Overall, literature describes the low impact of primary and further processing on the dietary significance of chicken meat, with the exception of wet chilling, where exposure can immediately influence water-soluble nutrients, but without significant impact on proteins or lipids [20]. 


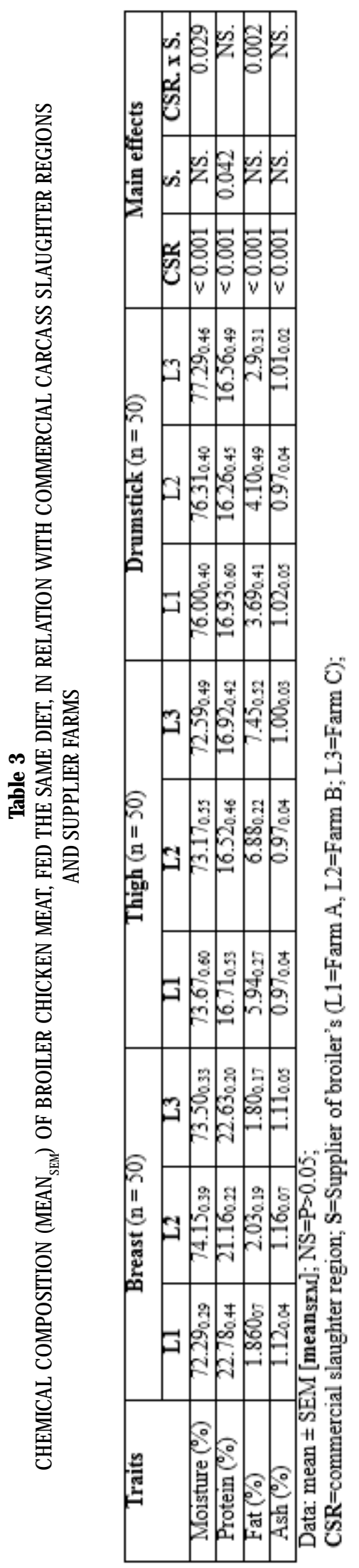

Results from the analyzed meat samples on the proximate chemical composition of broilers commercial slaughter cuts, shown in Table 3, reveals, for the major components, contents between $16.26-22.78 \%$ for proteins and $1.80-7.45 \%$ for total lipids. The commercial slaughter region had a major impact $(P<0.001)$ overall chemical composition, the breast having the highest protein and ash content and lowest values for fat and moisture. While the management of the suppliers influenced the muscle protein content $(P<0.05)$, it was observed that the interactions between suppliers and resulted

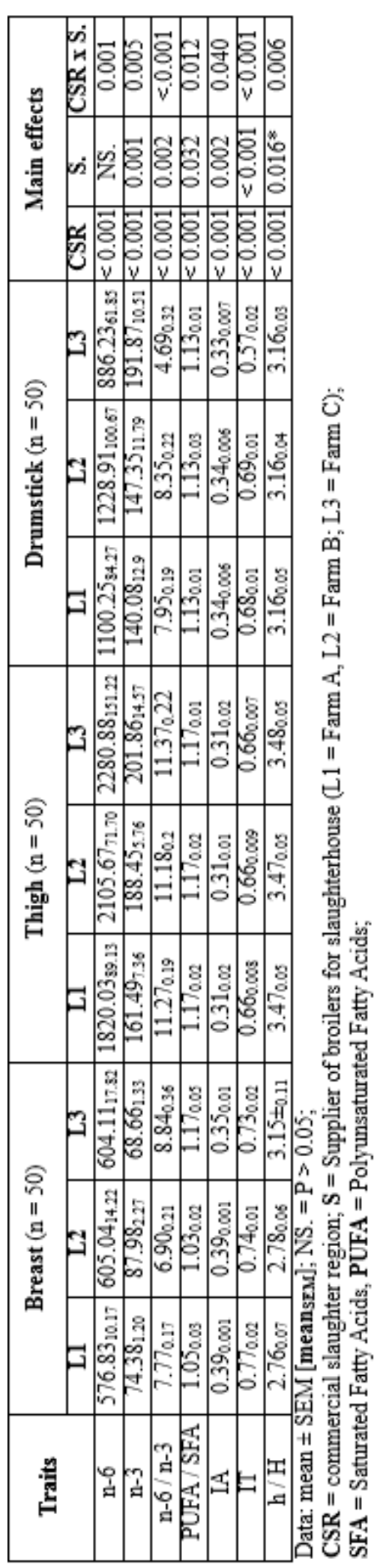

carcass commercial slaughter cuts had both an extensive and deeper effect, on fat $(P<0.01)$ and moisture $(P<0.05)$.

Our results are comparable to other study findings that indicated wide range of values for proteins, lipids and minerals, between $18.4-23.4 \%, 1.3-6.0 \%$, respectively $0.8-1.2 \%$ [31]. The fatty acid composition and their health-related lipid indicators of breast, thigh and drumstick meat of birds fed on a cerealbased dietcentered on com, wheat, soy meal, sunflower meal, sunflower oil and supplemented with lysine, methionine and mineral complexes is provided in Tables 4 and 5.

The muscle fatcontent of these three commercial slaughter cuts was quantitatively mainly represented by 8 fatty acids, as follows: C18:2n-6c (LA), C18:1n-9 an it's isomer C18:1n-7, 


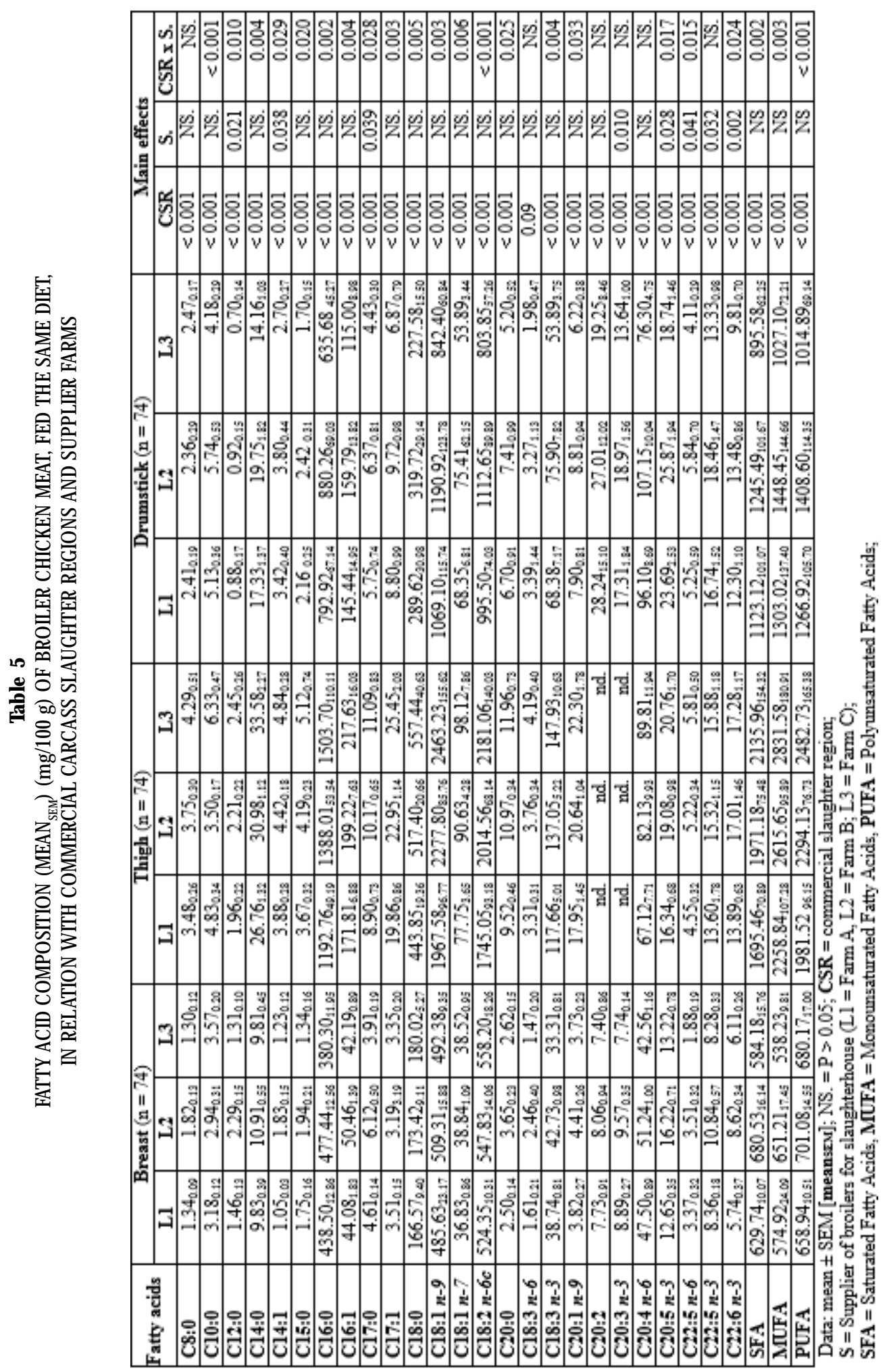

C16:0, C18:0, C18:3n-3 (LNA), C16:1, C20:4n-6 (AA) and C20:5n-3 (EPA). The literature reports the same decreasing order of concentration for the main fatty acids of broiler meat, important for human nutrition (LA, LNA, AA, EPA) as a result of the dietaryinclusion of oil sources rich in $n$-3polyunsaturated fatty acids. [32]. More than that, because these FA are recommended for human nutrition due to their ability to minimize the probability of lifestyle-related diseases occurrence [33-35], the recent researches centered on $n$ 3 PUFA targeted broiler meat enrichment through new (ultrasound-assisted nano-emulsion preparation [36] and consecrated strategies, like direct feed supplementation [37-46]. These approaches are used to minimize ù-6: ù-3 ratio in human diets $[47,48]$.
As we mentioned, in agreement with the values of total fat content, the predominant lipid fractions in broiler meat is displayed in Figure 1, monounsaturated fatty acids (MUFA) ranging between $28.97-38.04 \%$ of the total IMF. C18:1 n-9 is the mostimportantin the MUFA group, with an average overall value of $85.18 \%$ of total MUFA.

PUFA fraction is the most important group, with average values between $31.85-39.61 \%$ of total FA, C18:2n- $6 \mathrm{C}$ and $\mathrm{C} 18: 3 \mathrm{n}-3$ being found to be the dominant ones, responsible for $83.77 \%$ and $5.72 \%$ of total PUFA. The total SFA content of breast, thigh and drumstick meat did not differ between suppliers ( $P>0.05)$, although thigh and drumstick had the higher content, which is unfavorable to human health [49]. The overall average values for this fraction were between 

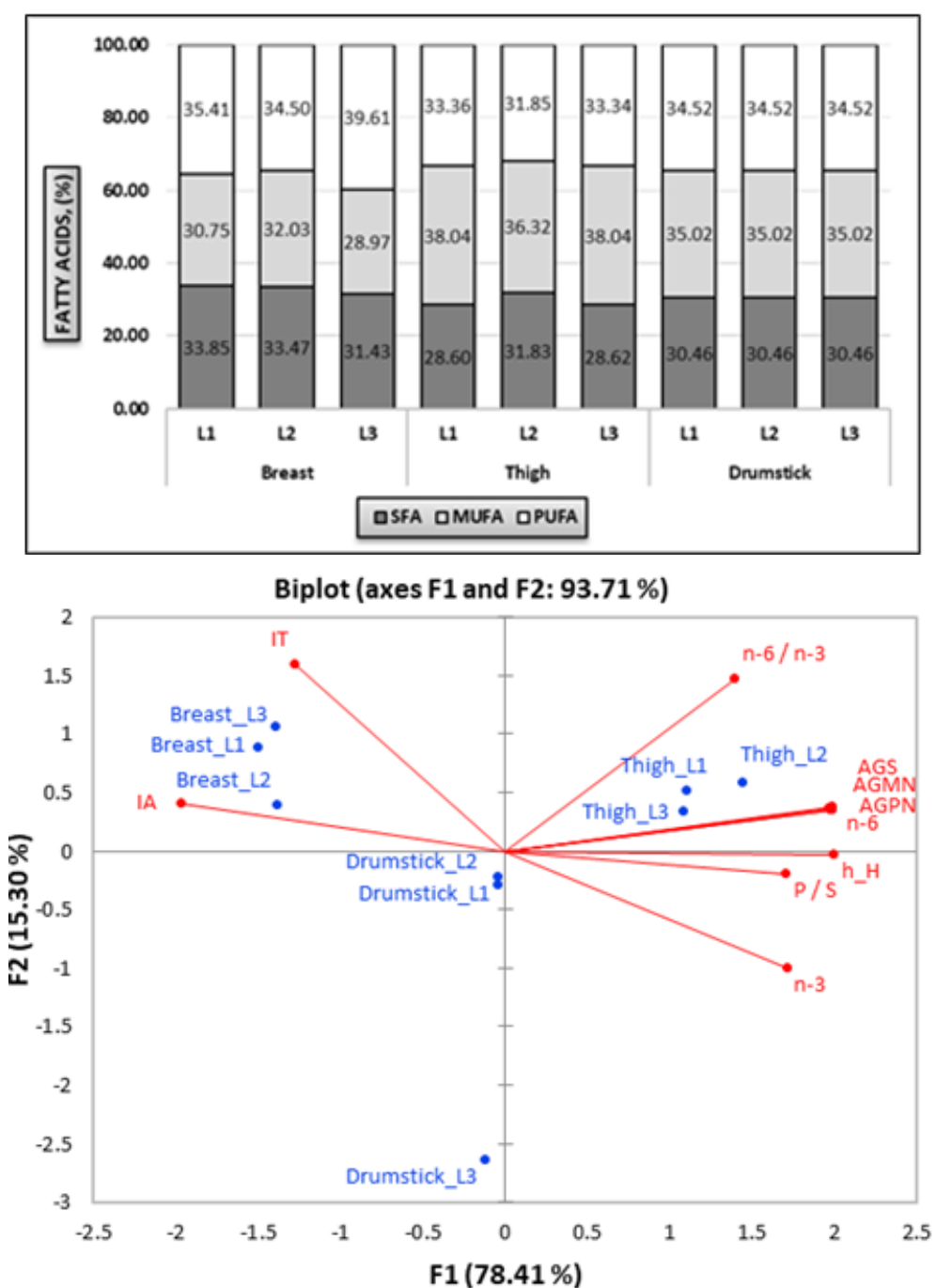

Fig. 1 Composition of fatty acids groups (\%) in broiler meat, in accordance with their commercial slaughter cuts (breast, thigh, drumstick) and supplier farms (L1, L2, L3)

Fig. 2 Principal component analysis for some fatty acids' groups and indexes in different commercial slaughter regions
28.60-33.85\% ot total 1 A. Here, C Ib:U was the most abundant in terms of quantity (70.17\% of total SFA), followed by C18:0, (26.22\% of total SFA).

In our study there is an evidentstatistically significant effect $(P<0.001)$ of CSR on each fatty acid content, with less extensive rate for $C 18: 3 n-6(P<0.05)$. The obvious findings highlighted thatFarm $B$ supplied broilers with a delivered higher content of beneficial fatty acids (LA, LNA, AA, EPA, DHA) in breasts and drumstick, while for thigh Farm $C$ had the best results. For C20:5n-3 (EPA), it was noted that the quantity of the drumstick lipids was comparatively nearly two times greater than that of the IMF breast muscles ( $P<0.001)$.

Dietary incorporation of sunflower meal and oil lowered the $\mathrm{C} 18: 2 \mathrm{n}-6 \mathrm{c}$ (LA) content in breast, but not in thigh and drumstick meat. The same pattern is retained and for some undesirable saturated fatty acids (USFA), such as C10:0, C12:0, C14:0, C16:0, C17:0 and C20:0.

C18:1 was the major MUFA, while PUFA was mainly defined by $C 18: 2 n-6 c$. No statistical differences $(P>0.05)$ were found in the whole monounsaturated fatty acids (MUFA) and total polyunsaturated fatty acids (PUFA) contents of breast, thigh and drumstick meat between suppliers, only CSR and interaction CSR x S had a significant, but specific effect on almost all FA.

Meatfatty acids profiles of chicken meat(SFA, MUFA, PUFA, $n-3, n-6)$, and the ratios among them, showed a significant effect on meat of CSR, source or their interaction, that can be attributed to the implementation of the dietary strategy and feed consumption (Table 4).

Descriptive data of lipids health related parameters have confirmed, through PUFA n-6/n-3 index values, that the breast muscles have the lowestratios $(P<0.001)$, in a context where the literature indicate an optimum value ratio of 4:1 [35].
Lipid nutritional quality indices for adipose tissue ranged from 0.31 to 0.39 for $I A$, respectively 0.57 and 0.77 for IT. According to the relative contents of the particular groups of fatty acids, the thigh lipids showed the lowest atherogenic $(I A ; P<0.001)$ and thrombogenic (IT; $P<0.001)$ indexes in comparison with the analyzed fats of drumstick and breast muscles (Table 4). This image is clearly represented throughout the principal component analysis (PCA), where CSR samples were displayed in the multi-dimensional space of the newly calculated variables. The firsttwo PCs calculated from these descriptors account for $93.71 \%$ of the total data variability, as shown in Figure 2.

IT and IA indices are strongly correlated with breastmuscle lipids composition, being adjacent and related with F1 plane in a negative way. The lipids of drumstick have loading values affiliated stronger to F2 plane. The thigh meat samples are positively correlate with F1 plane, having lipids strongly related and positively described by all health-related indices. As anticipated, studied CSR and their FA profiles reflected the FA composition of bird's diet fat (especially sunflower oil), this type of supplementation being company nutritional strategy, based on literature studies $[50,51]$.

\section{Conclusions}

The proximate chemical composition of the commercial slaughter cuts revealed breast superiority, the obtained values, especially for proteins (16.26-22.78\%) and lipids $(1.80-7.45 \%)$ being mainly affected by region $(P<0.001)$. Meat fatty acid profile $(P<0.001)$ was affected by commercial slaughter regions (CSR) and interactions between CSR and supplier farms (Farm A, B, and C) at different levels, with quantitative values comparable to 
those mentioned in the literature, with emphasis on dietary manipulation. Total content of SFAs, MUFAs and MUFAs had the highest level in the thigh $(P<0.001)$. Farm $B$ supplied broilers with a delivered higher content of beneficial fatty acids (LA, LNA, AA, EPA, and DHA) in breasts and drumstick, while for thigh Farm $C$ had the best results.

Although the results of the current study demonstrate that the fatty acid profile in edible tissues (breast, thigh and drumstick) depends of the feed composition, it definitely can be influenced and by the performance management of the supplier farms in all aspects, such as: nutritional management, training of the people or degree of the good raising practices (GRP) implementation. This assessment played an active role in the future execution of the company brand growth plan.

\section{References}

1.PEREIRA, P.M., VICENTE, A.F., Meat Sci., 93, no. 3, 2013, p. 586.

2.WEBB, E.C., O'NEILL, H.A., Meat SCi., 80, 2008, p. 28.

3.SCOLLAN, N.D., PRICE, E.M., MORGAN, S.A., HUWS, S.A., SHINGFIELD, K.J., Proc. Nutr. Soc., 76, 2017, p. 603.

4.DE SMET, S., RAES, K., DEMEYER, D., Anim. Res., 53, 2004, p. 81. 5.ZHANG, W., XIAO, S., SAMARAWEERA, H., LEE, E.J., AHN, D.U., Meat Sci., 86, 2010, p. 15.

6.SILBERGELD, E. K., Global Transitions, 1, 2019, p. 83.

7.BOGOSAVLJEVI-BOSKOVI, S., PAVLOVSKI, Z., PETROVI, M.D., DOSKOVI, V., RAKONJAC, S., Afr. J. Biotechnol., 9, no. 54, p. 9177.

8.WOOD, J.D., ENSER, M., FISHER, A.V., NUTE, G.R., SHEARD, P.R., RICHARDSON, R.I., Meat Sci., 78, 2008, p. 343.

9.***, E.U. REPORT "Report to the European Parliament and the Council on the application of Directive 2007/43/EC and its influence on the welfare of chickens kept for meat production, as well as the development of welfare indicators".

10.EL-KATCHA, M.I., EL-KHOLY, M.E., SOLTAN, M.A., EL-GAYAR, A.H., J. Poultry Sci., 2, 2014, p. 71.

11.BARCLAY, W., ABRIL, R., ABRIL, P., WEAVER, C., ASHFORD, A., World Rev. Nutr. Diet, 83, 1998, p. 61.

12.FRITSCHE, K.L., CASSITY, N.A., HUANG, S., Poultry Sci., 70, 1991, p. 1213.

13.AHMAD, H., TIAN, J., WANG, J., KHAN, M.A., WANG, Y., ZHANG, L., J. Agric. Food Chem., 60, 2012; p. 7111.

14.ALAGAWANY, M., ELNESR, S.S., FARAG, M.R., ABD EL-HACK, M.E., KHAFAGA A.F., TAHA, A.E., TIWARI, R., Animals, 9, 2019, p. 573.

15.LEE, S.S., WHENHAM, N., BEDFORD, M.R., Animal Nutrition 5, 2019, p. 11.

16.SAEED, M., YATAO, X., HASSAN, F. U., ARAIN, M. A., ABD EL-HACK, M. E., NORELDIN, A. E., SUN, C., Int. J. Mol. Sci., 19, 2018, p. 462. 17.YAN, L., KIM, I. H., J. Appl. Anim. Res., 41, 2013, p. 392. 18.PASCARIU, S.M., POP, I.M., SIMEANU, D., PAVEL, G., SOLCAN, C., Braz. J. Poultry Sci., 19, no. 2, p. 191.

19.MOTTET, A., TEMPIO, G., Worlds Poultry Sci. J., 73, no. 2, 2017, p. 245. 20.MIR, N.A., RAFIQ, A., KUMAR, F., SINGH, V., SHUKLA, V., J. Food Sci. Technol., 54, no. 10, 2017, p. 3001.

21.AHIWE, E.U., OMEDE, A.A., ABDALLH M.B., IJ I, P.A., Animal Husbandry and Nutrition, Chapter 6, 2018, p. 115.
22.SUKHIJA, P. S., PALMQUIST, D. L., ý. Agric. Food Chem., 36, no. 6, 1988, p. $1202-1206$.

23.***, AOAC (2000). Official methods of analysis of AOAC. International 17th edition; Gaithersburg, MD, USA Association of Analytical Communities. 24.FOLCH, J., LEES, M., SLOANE STANLEY, G. H., J. Biol. Chem., 226, 1957, p. 497.

25.FRUNZA, G., SIMEANU, D., POP, I. M., BOISTEANU, P. C., STEFAN, M., Rev. Chim. (Bucharest), 70, no. 2, 2019, p. 174.

26.PAPUC, C., CRIVINEANU, M., NICORESCU, V., PAPUC, C., PREDESCU, C., Rev. Chim. (Bucharest), 63, no. 12, 2012, p. 1198.

27.LUP, F., POP, I. M., SIMEANU, D., VICAS, S., SIMEANU, C., MIERLITA, D., Rev. Chim. (Bucharest), 69, no. 1, 2018, p. 222.

28.ULBRICHT, T. L., SOUTHGATE, D. A. T., The Lancet, 338, 1991, p. 991. 29.POPOVA, T., IGNATOVA, M., PETKOV, E., STANISIC, N., Arch. Anim. Breed., 59, 2016, p. 319.

30.FERNANDEZ, M. L., WEST, K. L., J. Nutr., 135, 2005, p. 2075.

31.CULIOLI, J., BERRI, C., MOUROT, J. Sci. Aliment, 23, no. 1, 2003, p. 13. 32.KALAKUNTLA, A.S., NAGIREDDY, A.N.K., PANDA, B.A.K, NARASIMHA JATOTH, A., RAGHUNANDAN THIRUNAHARI, A., VANGOOR, R.R., Anim. Nutr., 3, 2017, p. 386.

33.SIMOPOULOS, A.P., Biomed. Pharmacother., 56, 2002, p. 378.

34.SIMOPOULOS, A.P., Exp. Biol. Med., 233, no. 6, 2008, p. 674.

35.SIMOPOULOS, A.P., Nutr., 8, 2016, p. 128.

36.ABBASIA, F., SAMADIA, F., JAFARIB S.M., RAMEZANPOURC, S., SHAMS-

SHARGHD, M., J. Funct. Foods, 57, 2019, p. 373.

37.LOPEZ-FERRER, S., BAUCELLS, M.D., BARROETA, A.C., GRASHORN, M.A., Poultry Sci., 80, no. 6, 2001, p. 741.

38.LOPEZ-FERRER, S., BAUCELLS, M.D., BARROETA, A.C., GALOBART, J., GRASHORN, M.A., Poultry Sci., 80, no. 6, 2001, p. 753.

39.CHEONG, A. M., TAN, C. P., NYAM, K. L., Ind. Crop. Prod., 87, 2016, p. 1.

40.BETTI, M., PEREZ, T.I., ZUIDHOF, M.J., RENEMA, R.A., Poultry Sci., 88, 2009, p. 1740.

41.BETTI, M., SCHNEIDER, B.L., WISMER, W.V., CARNEY, V.L., ZUIDHOF, M.J., RENEMA, R.A., Poultry Sci., 88, 2009, p. 1085.

42.JIA, W., ROGIEWICZ, A., BRUCE, H.L., SLOMINSKI, B.A., Can. J. Anim. Sci., 90, 2010, p. 203.

43.ELKIN, R.G., YING, Y., HARVATINE, K.J ., J . Agr. Food Chem., 63, 2015, p. 2789.

44.APPERSON, K.D., CHERIAN, G., Poultry. Sci., 96, 2016, p. 1228.

45.KONIECZKA, P., CZAUDERNA, M., SMULIKOWSKA, S., Anim. Feed Sci. Tech., 223, 2017, p. 42.

46.SHAHIDI, F., AMBIGAIPALAN, P., Ann. Rev. Food. Sci. Technol., 9, 2018, p. 345.

47.GIVENS, D.I., GIBBS, R.A., Lipids, 40, 2005, p. 121.

48.GIVENS, D.I., GIBBS, R.A., P. Nutr. Soc., 67, 2008, p. 273.

49.KANAKRI, K., CARRAGHER, J., HUGHES, R., MUHLHAUSLER, B., GIBSON, R., Br. Poultry Sci., 58, no. 3, 2017, p. 283.

50.SCAIFE, J.R., MOYO, J., GALBRAITH, H., MICHIE, W., CAMPBELL, V., Br. Poultry Sci., 35, 1994, p. 107.

51.HRDINKA, C., ZOLLITSCH, W., KNAUS, W., LETTNER, F., Poultry Sci., 75, 1996, p. 208.

Manuscript received: 12.11 .2019 